Beata Wolfigiel*

Agnieszka Czerw ${ }^{* *}$

\title{
A new method to measure flow in professional tasks - A FLOW-W questionnaire (FLOW at Work)
}

\begin{abstract}
The aim of the article is to present a new Polish tool for measuring the flow experience in professional tasks a FLOW-W Questionnaire. The questionnaire was inspired by Csikszentmihalyi's (1990) flow theory and flow in Bakker's work (2008). On its basis a set of positions was established, on which subsequently an exploratory (study 1, N = 101) and confirmatory (study 2, $N=275$ ) factor analysis was conducted. The analysis showed the possibility of a uni- or bifactorial solution. After checking the theoretical and empirical validity of both solutions, the unifactorial solution was adopted. The validity of the questionnaire was examined, i.a. by correlations with theoretically related variables: work engagement with the UWES questionnaire (Szabowska-Walaszczyk, Zawadzka, Wojtaś, 2011) and affect at work (Zalewska, 2002). The studies showed a significant positive correlation between flow at work and work engagement (0.84) and between flow and positive affect (0.74). The reliability of the questionnaire is very high; $\alpha=0.96$. The tool has very good psychometric properties.
\end{abstract}

Key words: job satisfaction, motivation, questionnaire, engagement, flow

\section{Introduction}

The flow denoting a very specific subjective feeling which is experienced during the execution of various activities, has been for years the research objective in many countries all over the world (Csikszentmihalyi, 1988, 1990, 2000; Csikszentmihalyi and LeFevre, 1989; Rheinberg, 2006; Engeser, Schiepe-Tiska, 2012; Harmat, Andersen et al., 2016). Unfortunately, in Poland flow still remains outside the scope of scientific interest. It is interesting for practitioners (e.g. coaches), but almost completely ignored by researchers. It seems to be worthwhile to change that. Therefore, the aim of this article is to present an originally developed tool for measuring the flow experience in professional tasks.

According to the definition developed by Mihaly Csikszentmihalyi (1990) who is the author of the concept - flow is an optimal autotelic experience, deep satisfaction or elation when the body or mind undertakes a large voluntary effort to accomplish something difficult and worthwhile. The flow experience is autotelic, which means it is rewarding on its own and associated with the occurrence of internal motivation. It is worth noting that

\footnotetext{
* University of Silesia, Faculty of Social Sciences, Katowice

** University of Social Sciences and Humanities, Faculty in Poznań

Corresponding author: Beata Wolfigiel
}

flow appears in different areas of life and, as presented by numerous studies, occurs most often while doing sports, hobbies and when learning and working (Csikszentmihalyi, 1990, 2000; Csikszentmihalyi and LeFevre, 1989; Engeser, Schiepe-Tiska, 2012; Harmat, Andersen et al., 2016).

The flow concept also contributed to the creation of experimental curricula, it is used in training business people, designing services and products related to spending leisure time (Csikszentmihalyi, 1990). It has found application in: clinical psychotherapy, rehabilitation of juvenile offenders, organising classes in retirement homes, in occupational therapy for the intellectually disabled (Csikszentmihalyi, 1990) and in professional coaching (Ochinowski, 2009).

The author of the flow concept, as mentioned earlier, is Mihaly Csikszentmihalyi who has been studying flow experiences since 1965, along with scientists around the world, i.a. in Germany, Italy, Japan, Korea and Australia (list of studies: Csikszentmihalyi, 1988, 1990, 2000; Csikszentmihalyi and LeFevre, 1989; Rheinberg, 2006; Engeser, Schiepe-Tiska, 2012; Harmat, Andersen et al., 2016). Interestingly, despite the worldwide popularity of flow studies, there are no researchers absorbed with this 
topic in Poland. After analysing the available literature and research reports, only one Polish scientific study concerning the research in flow among swimmers, conducted by M. Mikicin (2007), was found. Also, Porczyńska made reference to this idea in her doctoral thesis, she did not use the term of flow directly, but used the notion of happiness (Porczyńska, 2006). It seems that in the face of so many research projects and practical implementations of this concept throughout the world (Csikszentmihalyi, 1988, 1990; Engeser and Schiepe-Tiska, 2012, Harmat, Andersen et al., 2016) it is worth trying to verify it in studies which are conducted in our country.

\section{Flow experienced in a work situation}

The knowledge of flow is also used in a work situation, and the best-known person in the scientific community who deals with this is professor Arnold Bakker. He defines (Bakker, 2008) flow in professional tasks as a short-lasting peak experience happening during work and characterised by: absorption - a state of total concentration where employees are preoccupied with work; work enjoyment - an effect of cognitive and affective evaluation of experienced flow at work; intrinsic work motivation performing a professional task in order to experience the pleasure and satisfaction that comes from this activity.

Bakker's research results (2008) indicate that work enjoyment is the most important predictor of an employee performance in their standard occupational duties. On the other hand, the intrinsic motivation (but not absorption) is the most important predictor of an employee performance in tasks that go beyond the standard duties, which increase the efficiency of the organisation. Other studies conducted among secondary school teachers (Salanova, Bakker, Llorens, 2006) indicate that organisational resources such as social support, innovation or clear goals have a positive impact on flow occurrence, as well as personal resources understood as a self-efficacy at work. Interestingly, the flow experience has positive impact on personal and organisational resources. So we are dealing here with the feedback between flow and personal or organisational resources.

One of the practical applications of the knowledge about the optimal experience in human resources management is an example of the Ericsson company and its vice-president Stefan Falk who was influenced by the book "Flow" (Csikszentmihalyi, 1990) and implemented into his organisation a special system to increase the efficiency and work engagement (Pink, 2012). Following the recommendations of $\mathrm{M}$. Csikszentmihalyi some attempts were made to create the conditions conducive to concentration, precise matching of the employees' tasks to their abilities and to maintaining constant, close contact with the manager. It turned out that this motivational method proved to be very effective, and the staff felt very satisfied with it. Falk moved then to a Swedish company Green Cargo, where he developed a method of training managers, which acquainted them with the functioning of the flow theory. After 2 years the Green Cargo company became profitable for the first time in 125 years, and the management gives the newly discovered "flowcentrism" as the main reason for it. Following this example, other companies such as Microsoft, Patagonia and Toyota are trying to create an environment encouraging flow (Pink, 2012).

It is worth noting that so far the conducted research has shown mainly positive consequences of experiencing flow. On the other hand, it can be also assumed that flow experiences at work are so rewarding that they can lead to an excessive and thus probably harmful involvement in work, which can be a significant problem. Nowadays it is increasingly more common to pay attention to the 'dark side' of flow, which can be manifested as addiction, antisocial behaviour and willingness to take too much risk (Schuler, 2012). So far, however, insufficient research has been conducted on this subject to draw any unequivocal conclusions. Nevertheless, the preliminary reports indicate that flow can be associated for example with addiction to computer games and the internet. Sometimes, the desire to experience flow leads to antisocial behaviours such as fights and thefts, especially when someone is suffering from the lack of flow in other areas of life. It can also provoke neglecting other tasks that do not lead to flow, but are equally important (e.g. the lack of time for the family, ignoring the need for sleep). Therefore, to prevent negative consequences of flow, it is worth to strike the balance - to broaden the spectrum of the flow experience onto various spheres of life, without focusing excessively on one of them (Schuler, 2012).

Flow is not easy to be operationalized because the definitions of this phenomenon often describe various constructs which accompany experiencing flow, are its cause or its consequence. However, the most frequently recurring constituent components of flow are skills and challenge. According to Csikszentmihalyi (1990) these are the most important conditions for achieving flow. In addition, test results reviewed by Csikszentmihalyi (1990, 2005), referring to components of experiencing flow (regardless of situation) point to the importance of such elements like:

- Difficult tasks which are nonetheless suited to high skills levels of a subject,

- Clearly defined objectives - in activities where there is no pre-determined objective, one needs to develop a strong sense of what he or she is going to achieve,

Feedback - the ability to recognise them is important here because such information provides us with the knowledge about the progress in performing an activity,

- Concentration - which means focusing attention exclusively on the performed action,

- A sense of control over the activity performed, which can be very subjective in nature, it is often only the impression of control e.g. the sense of the possibility to control the danger in risky activities,

- Loss of self-consciousness - that is, the loss of perceiving oneself as something separated from the rest of the world, the feeling of oneness with the environment,

- Transformation of time - the sense of time often has no connection with its real passage, time either stops or flows faster. 
Whereas, among the factors that condition the occurrence of flow at work, Csikszentmihalyi (2004) indicates the freedom to choose the method of achieving an objective, tailoring tasks both to skills and the value of the employee and his actual psychophysical condition, setting clear and understandable organizational goals and the employee themselves. He also stresses that the feedback from other people or from the employee's internal standards, as well as visible work effects are very important for the flow experience.

\section{Methods of measuring flow}

Initially, the flow experience was investigated by conducting interviews, but other measurement tools gradually developed over time. Nowadays, four main ways of measurement can be distinguished: narrative, active, experience sampling and questionnaires.

In the narrative method respondents describe the flow experience from the past and then evaluate it using a research tool e.g. Privette's "Experience questionnaire" (Privett, Bundrick, 1987). It seems that narrative methods are among the easiest ones to use. However, the information obtained through them may be distorted because of the difficulties in extracting them from memory.

On the other hand, in active methods respondents first perform a specific type of activity (e.g. a group computer exercise), then they are asked to assess these experiences (Novak, Hoffman, 1997). Active methods can picture the flow experience better, especially when a person completes the test method immediately after its experience, memories are not distorted then. The active method is particularly useful for measurements referring to specific actions that can be performed in laboratory conditions (Csikszentmihalyi, 2000). In other cases, unfortunately, it is very difficult.

Another type of method is the Experience Sampling Method. The method stipulates that respondents carry a pager which signals them each day during a week-long period when they have to assess an action which is being currently performed. They have to evaluate a particular activity using a tool, that they carry, that serves to assess the flow (Novak, Hoffman, 1997; Csikszentmihalyi, 2000). Csikszentmihalyi (1990) recommends the method of experience sampling as the one that allows you to obtain the most precise data about the shape and the quality of everyday life. In contrast, S. Jackson and H. Marsh (1996) pointed out that more research is required to verify its reliability and validity and emphasised practical problems associated with its use - difficulty in application and incomplete results (Kimiecik and Stein, 1992). In addition, the signal of the pager can interrupt flow and cause difficulties in a reliable reconstruction of this experience (Engeser, Schiepe-Tiska, 2012).

Currently, questionnaires are used more and more often to study flow because of their reliability and validity and ease of use. An example of this method is a questionnaire to study the flow at work - The WorkreLated Flow inventory (WOLF) by A.B. Bakker (2008).
The questionnaire measures flow components which are: absorption, work enjoyment and intrinsic work motivation. A.B. Bakker's questionnaire was based on a study of seven professional groups with a total of 1346 people. High scores in each of the scales simultaneously indicate the flow experience. Another tool is Die-Flow Kurzskala FKS - a scale to study flow created by F. Rheinberg (2003). The Flow State Scale created by S. Jackson (Tenenbaum, Fogarty, Jackson, 1999) is also popular - a questionnaire used to study the flow experience primarily among athletes.

Of course, each method has its strengths and weaknesses, and its choice should be dependent primarily on the purpose of the study. However, one should be first of all aware that many tools being in use examine the conditions of experiencing flow, its characteristics and consequences at the same time. One such example is The Flow State Scale (Tenenbaum, Fogarty, Jackson, 1999). It seems that for the benefit of the measurement these components should be clearly distinguished. In this respect the WOLF questionnaire by Bakker (2008) is a good example of such a method.

\section{The FLOW-W Questionnaire - stages of formation}

The original questionnaire, presented here, for studying the frequency of experiencing flow in the performance of professional tasks was inspired by the theory of flow in Bakker's work (2008), by his questionnaire, The Flow State Scale (Tenenbaum, Fogarty, Jackson, 1999), and also by the Scale of Experiencing Happiness (Porczyńska, 2006) and Die-Flow Kurzskala FKS (Rheinberg, 2003). Proprietary items were formed on the basis of descriptions of flow from literature and proprietary research (Wolfigiel, 2003), using the procedure of paraphrase, for example: "My consciousness was completely absorbed by the performed action", "I would like to still relive those moments, which professional activity gave me." On their basis a set of 24 items subjected to further analysis was created. A Polish philologist made an assessment of the linguistic correctness of questionnaire items.

\section{The analysis of the FLOW-W Questionnaire content relevance}

The content relevance was determined with the method of competent judges. The experts were five psychologists with $\mathrm{PhD}$ titles and specialization in occupational psychology or social psychology, who assessed their knowledge of the concept of flow at a very good or good level. Four psychologists have worked in the profession for between 20 and 33 years, one has worked for 6 years.

The competent judges were instructed to assess to what extent the presented items of the questionnaire are useful (on a scale from 1 to 5) to evaluate the experience of the flow state. The content validity ratio by Lawshe (Lawshe, 1975 in: Hornowska, 2003) was used for calculation of compliance with the ratings of the judges. In the questionnaire the items which received a positive value greater than zero were retained, which means that more than half of the judges assessed them highly. Nine of 
them obtained the value of 1 so all the judges agreed that items are very useful. The Content Validity Index for the entire tool amounts to 0.76 .

\section{Study I - the constructional study}

The study was conducted in $2011^{1}$ on a sample of 101 people in different occupations $(M=34, S D=8.9)$. The group consisted of 64 women and 37 men. Types of employment: 69 people were bound by an employment contract and 32 had other forms of employment (selfemployment, entrepreneurship, freelancing). The job seniority in the current profession varied greatly from 1 month to 23 years. Education: from secondary to higher education with a $\mathrm{PhD}$ degree. The subjects were recruited through personal channels and by e-mail. They received an invitation with an explanation as to the course and purpose of the study and a link to the electronically prepared research form. The participation in the research was undertaken by people who expressed willingness to do so. The participants had their anonymity guaranteed and were informed about scientific purposes of the research.

At this stage of the research the exploratory factor analysis was conducted using the principal component analysis method with the Oblimin rotation. First of all, the compatibility of the received data with the assumptions of the analysis was checked. The value of $K M O=0.945$ and the result of the Barlett's test of sphericity was at a $p=0.001$ level proved satisfactory. Three factors of eigenvalue equal to 1 or higher, which explain a total of $72.31 \%$ of variance, were identified in the course of exploratory factor analysis. While analysing the scree plot (Figure 1) one can notice that its steepness suggests rather 2 factors. Therefore, a bifactorial solution, which explains $67.46 \%$ of variance, was adopted.
The final version of the assignment of questionnaire items to two separate factors (Table 1) was created after elimination of items with factor loads of less than 0.70 . The final questionnaire consists of 15 items.

Factor 1 - ABSORPTION (7 items, $\alpha=0.94$ ) - complete preoccupation with the performed task to the point where the world around ceases to exist. This preoccupation is associated with absolute concentration on the currently performed activity.

Example items: "When I was working I forgot about the world around me," "My mind was completely focused on the performed activity."

Factor 2 - POSITIVE EMOTIONS (8 items, $\alpha=0.95)-$ denotes an experience giving profound satisfaction, sense of purpose, one which is satisfying in itself. Due to the presence of positive emotions, a person is willing repeat such experiences even though they require a significant effort. Examples items: "I carried out the task in my job with enthusiasm," "I would like to constantly experience moments which my professional activity has brought me."

\section{Study II - the confirmatory study}

As five years have passed since the first study, it seemed sensible to confirm whether the structure of the questionnaire obtained back then is still relevant. The next study was conducted in 2016 on a slightly larger sample $(N=275)$. The subjects were aged between 20 to 68 , the average age was 35.5 years, $S D=7.8$. The group consisted of 194 women and 91 men. Types of employment: 180 people were bound by an employment contract and 95 had other forms of employment (selfemployment, entrepreneurship, freelancing). The job

Figure 1. The scree plot of the 24-item version of FLOW-W - graphic interpretation of exploration factor analysis

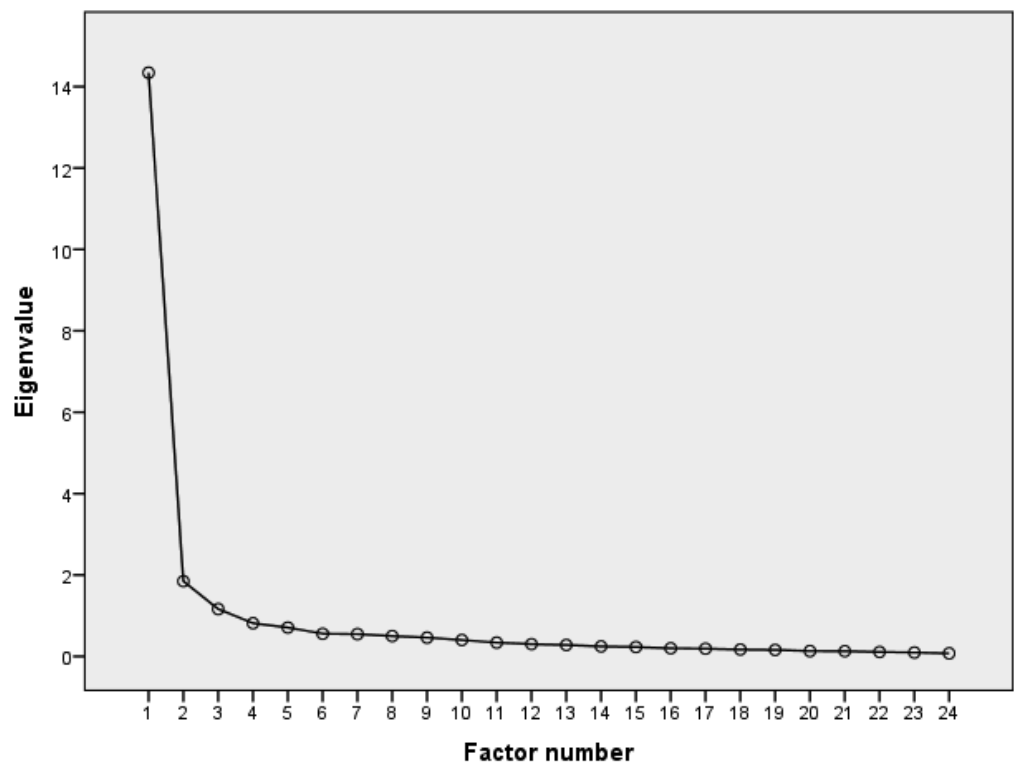

1 The results of this research have not been published yet. 
Table 1. FLOW-W exploratory factor analysis using Oblimin rotation with Kaiser normalization

\begin{tabular}{lcc}
\hline \multicolumn{1}{c}{ Items } & $\mathbf{1}$ & $\mathbf{2}$ \\
\hline My work gave me many positive emotions. & 0.910 & 0.081 \\
I enjoyed what I was doing, even if it was a difficult task. & 0.813 & 0.123 \\
I carried out my professional tasks with enthusiasm & 0.809 & 0.099 \\
I experienced a lot of fun during the performance of the chosen professional task. & 0.807 & 0.091 \\
The performed work gave me a sense of fulfilment. & 0.768 & 0.145 \\
I was fascinated with my professional task. & 0.708 & 0.220 \\
The work that I was busy with was a reward in itself. & 0.707 & 0.234 \\
I would like to constantly relive the moments that professional activity gave me. & 0.701 & 0.131 \\
I was passionate about the task I performed at work. & 0.677 & 0.239 \\
The performance of a professional activity alone was highly rewarding for me. & 0.663 & 0.243 \\
My motivation emerged from the work itself and not from external rewards associated with it. & 0.662 & 0.110 \\
I was full of energy while performing the task. & 0.654 & 0.304 \\
When I dealt with the chosen professional task, I experienced the moments of maximum & 0.639 & 0.245 \\
satisfaction. & & \\
External benefits of my work were more important for me than the activity at work itself. & 0.619 & 0.326 \\
I could get excited about the work despite unfavourable external conditions & 0.570 & 0.338 \\
I felt that even if I did not have to work at all I would still be doing this job. & 0.556 & 0.252 \\
I was completely absorbed in the work. & 0.147 & 0.817 \\
When I was working, I forgot about everything else around. & 0.061 & 0.816 \\
When I was involved in a professional task, nothing else mattered. & 0.060 & 0.799 \\
I was "completely immersed" in performing a professional task. & 0.182 & 0.779 \\
When I was working, I did not think about anything else. & 0.001 & 0.725 \\
My consciousness was completely absorbed by the activity I performed. & 0.246 & 0.725 \\
I was obsessed with what I was doing. & 0.244 & 0.706 \\
I worked so intensively that I lost the track of time. & 0.169 & 0.635 \\
\hline
\end{tabular}

seniority in the current profession was 8 years, $S D=6.8$ years, and the average job seniority was 13 years, $S D=7.7$ years. Education: from primary to higher education with a $\mathrm{PhD}$ or higher academic title. The subjects were recruited through social media. They received an invitation with an explanation as to the course and purpose of the study and a link to the electronically prepared research form. The participation in the research was undertaken by people who expressed willingness to do so. The participants had their anonymity guaranteed and were informed about scientific purposes of the research.

The collected data was subjected to factor analysis. The aim of this analysis was to assess whether the bifactorial structure obtained in the first study would be confirmed. For this reason, another factor analysis was conducted using the principal component analysis method with the Oblimin rotation and the assumption of the existence of 2 factors.

The value of $K M O=0.945$ and the Barlett's test of sphericity at a $p=0.001$ level were satisfactory.

The results of the factorial analysis showed that the bifactorial solution is possible to sustain. The scree plot (Fig. 2) suggests a uni- or bifactorial solution and the factor loading matrix (table 2) confirms the distribution of the positions in both factors analogously to the original one.

While analysing both the scree plot and factor loading matrix data one can observe that the obtained data may well suggest the adoption of a unifactorial solution. First of all, there is a very steep line on the first and second scree plot. Secondly, the factor loads of questionnaire items in 
Figure 2. The scree plot of 15-item version of FLOW-W - graphic interpretation of confirmation factor analysis

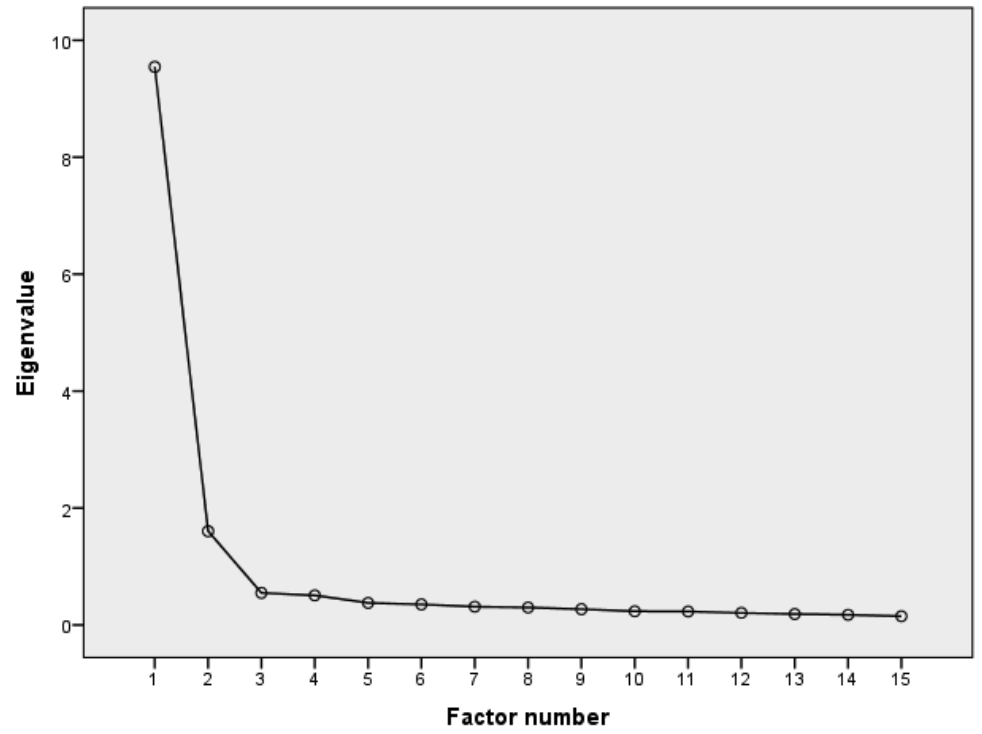

Table 2. FLOW-W exploratory factor analysis using Oblimin rotation with Kaiser normalization

\begin{tabular}{lcc}
\hline & \multicolumn{2}{c}{ The component } \\
\cline { 2 - 3 } & $\mathbf{1}$ & $\mathbf{2}$ \\
\hline item10 & 0.910 & 0.642 \\
item7 & 0.883 & 0.545 \\
item4 & 0.865 & 0.607 \\
item12 & 0.863 & 0.576 \\
item15 & 0.862 & 0.622 \\
item8 & 0.852 & 0.630 \\
item2 & 0.849 & 0.485 \\
item13 & 0.848 & 0.620 \\
item5 & 0.630 & 0.871 \\
item3 & 0.534 & 0.863 \\
item11 & 0.716 & 0.858 \\
item9 & 0.668 & 0.853 \\
item1 & 0.494 & 0.848 \\
item6 & 0.522 & 0.819 \\
item14 & 0.601 & 0.813 \\
\hline
\end{tabular}

both dimensions reach fairly high values, which in the majority of cases are greater than 0.5 . For this reason, the connection between two separate factors was examined. It turned out the correlation between the two questionnaire scales is $r=0.72 ; p \leq 0.01$, which indicates a very strong relationship. Taking all these indications into consideration, it was ultimately decided that the most reasonable solution is to adopt a unifactorial solution. The reliability of the questionnaire measured with the Cronbach's coefficient was very high: $\alpha=0.96$.

\section{The FLOW-W Questionnaire validity analysis}

During the analysis of the FLOW-W questionnaire structure, the analysis of the validity of flow measurement in professional tasks was also conducted on the same sample. Due to the lack of other tools to study flow at work in Poland, the validity of the FLOW-W questionnaire was analysed by examining the relationship between flow and variables theoretically associated with it. The chosen variables were: work engagement according to Schaufeli and Bakker (Schaufeli and Bakker, 2003; 2010) diagnosed with the UWES-PL questionnaire (Szabowska-Walaszczyk, 2010; Szabowska-Walaszczyk, Zawadzka, Wojtaś, 2011), and positive affect at work measured with one of the Job Affect Scale dimensions (Burke, Brief, George Robinson and Webster, 1989) as adapted by Zalewska - SAP (2002). The choice of these tools is justified by the similarity of the definitions of tested variables. Schaufeli and Bakker in their definition of engagement distinguish three factors: vigour, dedication, and absorption, which are understood as full concentration and involvement in the performed task, associated with the sense of the rapid passage of time, and difficulties in discontinuing the work (2003). Such absorption occurs while experiencing flow, as understood by Csikszentmihalyi (1990). Moreover, as described above, Bakker characterises flow at work also by absorption, work enjoyment, and intrinsic work motivation (2008). One can therefore assume that preoccupation is the connecting factor of flow and commitment to work.

In turn, the positive affect analysed through SAP denotes pleasant commitment, desire to live and enthusiasm (Zalewska, 2002), which is also consistent with the feelings declared by people experiencing flow (Csikszentmihalyi, 
1990). On these grounds it was assumed that flow at work should be positively associated with involvement in work and positive affect at work.

The results of the analysis indicate that the correlation between flow during professional tasks and professional work engagement was $r=0.84 ; p \leq 0.001$. A similarly high correlation between flow during professional tasks and positive affect at work: $r=0.74 ; p \leq 0.001$. Moreover, the relationship between flow and the second dimension of the SAP questionnaire, the negative affect, was examined. In this case the correlation was slightly lower and negative: $r=-0.46 ; p \leq 0.001$. These results are consistent with the assumptions and allow for recognising the questionnaire as accurate.

Apart from the examination of the relation of flow to other psychological variables, the validity of the questionnaire was examined by applying the FLOW-W result to questions directly related to the experience of flow at work, just as A.B. Bakker did (2008). For this purpose, we presented the respondents the following statement:

"I immerse in work, I lose the track of time, I am absolutely obsessed with what I do. I have the feeling that at this moment nothing else is important. I work at full speed, and I trust myself more than in any other situation. It is a fascinating and exciting experience that gives me the feeling of fulfilment and a deep sense of purpose in my work. I would like to constantly relive such moments."

Then the respondents were asked to assess whether they had ever had a similar experience in their work (yes / no) and how often it happened (from 1 - very seldom, to 5 - very often). It was assumed that there will be a difference in the result of the FLOW-W questionnaire between the groups of people experiencing and not experiencing flow at work, as well as a positive correlation between the result of the FLOW-W and the frequency of experiencing the feelings described in the text.

Analysis of responses to the first question about the fact that the experience of flow at work indicated that indeed people $(N=162)$ who have ever experienced the flow of work have significantly higher scores on the FLOW-W questionnaire than the people $(N=113)$, who did not have such experience. The difference is $t(273)=10.95$; $p=0.001$ between groups of people who responded affirmatively $(M=54.98, S D=10.40)$ and negatively $(M=40.71, S D=10.95)$.

As regards the second question - about the frequency of experiencing the described state - correlation was counted only in the group of people who responded affirmatively to the first question. In this way the people who stated that they had never experienced flow in their work were eliminated. It turned out that the correlation between the result of the FLOW-W questionnaire with the answer to the second question is strong and positive $(r=0.663 ; p \leq 0.001)$.

As can be seen both analyses of additional questions confirm the validity of the new questionnaire.

\section{Discussion of results and conclusions}

Adopting the subject of diagnosing flow experience at work in Polish conditions seems to be particularly important due to the lack of research tools applied in Poland in this area, as well as due to the almost total absence of scientific literature on flow in the Polish language. Given the extraordinary popularity of research in flow conducted worldwide, it would be unfortunate for Polish researchers to overlook this field of knowledge. That is why a Polish diagnostic tool based on theories recognised worldwide is an important contribution to the development of science.

The questionnaire for studying the frequency of experiencing flow, presented in this article, has good psychometric properties and it seems that it can be successfully used for scientific purposes. Due to the relatively small size of the groups in both studies, it should be concluded that the questionnaire is presently still an initial version. Nevertheless, this research tool will allow researchers to collect more data. After collecting a sufficiently large number of subjects (e.g. over 500 people) confirmatory factor analysis using adjustment indicators of theoretical model to the empirical data can be performed. For this reason, the publication of the article about the questionnaire is an important step in conducting research to verify its psychometric properties and the preparation of standards.

The limitations of these studies certainly lie in unequal sizes of the respondent groups of men and women. In the first study, women accounted for $63 \%$, men for $37 \%$ of the sample, in the second study, there were $70.5 \%$ women and only $29.5 \%$ men. It is therefore important to collect more data from working men. Then it would be possible to assess if gender is important for flow experiencing. This study verified whether there is a difference with relation to the gender, but the result was not statistically significant.

Another issue, which in this study was only controlled was the matter related to the education level, company size and form of employment. Unfortunately, in this case as well, the uneven distribution of the respondents in the groups does not give reliable results (it was found that there were no significant differences) concerning the possible impact of these employment parameters on the incidence of experiencing flow at work. Moreover, the type of profession seems significant for experiencing flow and it was not controlled here. Csikszentmihalyi (1990) argues that flow can be experienced in any type of situation, but still there are research results showing that there are activities that are particularly conducive to such experiences (Csikszentmihalyi, 2000). Of course, after collecting a sufficiently large and much more diverse sample group, the validity of unifactorial solutions should also be reassessed.

In addition, it is also important to bear in mind the difficulty of capturing the experience of flow in the survey questionnaire. Therefore, alternative methods of flow testing should be considered, as well as combining 
several methods in the full diagnosis of this phenomenon. On account of this, in further studies it is planned to more carefully consider the aforementioned environmental factors (related to employment characteristics) and subjective factors conditioning the experience of flow. Owing to this it will probably be possible to identify factors that increase the probability of flow experience in a work situation. In further research it is also worth taking a closer look at the possible consequences of experiencing flow in a work situation. This is a highly significant issue for the employee and for the organization in which they work. Since there are indications of the relationship between flow and the experience of well-being (high correlation between flow during professional tasks and positive affect at work: $r=0.74 ; p \leq 0.001$ ), the research in this area should be extended e.g. by verification whether all types of wellbeing (hedonistic, eudaimonistic) have the same sensitivity to the flow experienced by an employee.

Earlier in this article the probable negative consequences of experiencing flow at work were also mentioned. Therefore, in future studies it would be also useful to address this problem - for example, excessive involvement in work leading to distorting the balance between personal life and professional life.

Investigating not only the frequency of experiencing flow, but also its depth, would be an interesting complement to the research. It turns out that flow has many facets, and in our daily lives we encounter less intensive experiences. The research in the depth of flow was conducted by Giovanni Moneta (2012), who also draws attention to another way of approaching flow. The author argues that flow can have a purely hedonistic tone (pleasure) when the subject is characterised by high skills in situations perceived as a medium challenge. On the other hand, flow can bring about cognitive efficiency if we estimate the challenge as high, and have medium skills.

As can be seen, there are many areas of research related to the problems of flow at work, and the new questionnaire presented here may help in the development of this area of knowledge ${ }^{2}$.

\section{References}

Bakker, A.B. (2008). The work-related flow inventory: Construction and initial validation of the WOLF. Journal of Vocational Behavior, 72 $400-414$

Burke, M.J., Brief, A.P., George, J.M., Roberson, L., \& Webster, J. (1989). Measuring affect at work: Confirmatory analyses of competing mood structures with conceptual linkage to cortical regulatory systems. Journal of Personality and Social Psychology, 57, 1091-1102.

Csikszentmihalyi, M., \& LeFevre, J. (1989). Optimal experience in work and leisure, Journal of Personality and Social Psychology, 56(5), 815-822.

Csikszentmihalyi, M. (2000). Beyond Boredom and Anxiety: Experiencing Flow in Work and Play. 25th Anniversary Special Edition. San Francisco: Jossey-Bass Publisher.

Csikszentmihalyi, M. (2004). Good business. Leadership, flow and the making of meaning. New York: Penguin Book.
Csikszentmihalyi, M., \& Csikszentmihalyi, I.S. (1988). Optimal Experience: Psychological Studies of Flow in Consciousness. Cambridge: Cambridge University Press.

Csikszentmihalyi, M. (1990). Flow: The Psychology of Optimal Experience. New York: Harper Collins.

Engeser, S., \& Schiepe-Tiska, A. (2012). Historical lines and overview of current research on flow. In S. Engeser (ed.), Advances in Flow Research (pp. 1-22). New York: Springer.

Harmat, L., Andersen, F.L., Ullén, F., Wright, J., \& Sadlo, G. (ed.) (2016). Flow Experience: Empirical Research and Application. New York: Springer.

Hornowska, E. (2003). Testy psychologiczne. Teoria i praktyka [Psychological tests. Theory and practice]. Warszawa: Wydawnictwo naukowe Scholar.

Jackson, S., \& Marsh, H. (1996). Development and validation of a scale to measure optimal experience: The flow state scale. Journal of Sport \& Exercise Psychology, 18, 17-35.

Kimiecik, J.C., \& Stein, G.L. (1992). Examining flow experiences in sport contexts: Conceptual issues and methodological concerns. Journal of Applied Sport Psychology, Volume 4, Issue 2, 144-160.

Lawshe, C.H. (1975). A quantitative approach to content validity. Personnel Psychology, 28, 563-575.

Mikicin, M. (2007). Relationships between experiencing flow state and personality traits, locus of control and achievement motivation in swimmers. Physical Education and Sport, 51, 61-67.

Moneta, G.B. (2012). On the measurement and conceptualization of flow. In S. Engeser (ed.), Advances in Flow Research (pp. 23-50). New York: Springer.

Novak, T.P., \& Hoffman, D.L. (1997). Measuring the Flow Experience Among Web Users, Project 2000, Paper Presented at Interval Research Corporation, July 31. Vanderbilt University.

Ochinowski, T. (2009). Coaching biznesowy a psychologia pozytywna [Bussines coaching and positive psychology] In M. Sidor-Rządkowska (ed.), Coaching. Teoria, praktyka, studia przypadków [Coaching. Theory, practice, case studies], (pp. 170-188). Kraków: Wolters Kluwer Polska.

Pink, D.H. (2012). Drive. Warszawa: Studio Emka.

Porczyńska, A. (2006). Związek między wybranymi cechami osobowości a poczuciem sensu życia $i$ doświadczaniem szczéścia. Nieopublikowana praca doktorska [The relationship between selected personality traits and sense of meaning in life and experiencing happiness. Unpublished doctoral dissertation]. Katowice: Uniwersytet Śląski.

Privette, G., \& Bundrick, C.M. (1987). Measurement of Experience: Construct and Content Validity of the Experience Questionnaire, Perceptual and Motor Skills, 65, 315-332.

Rheinberg, F. (2006). Psychologia motywacji [Psychology of motivation]. Kraków: WAM.

Rheinberg, F., Vollmeyer, R., \& Engeser, S. (2003). Die Erfassung des Flow-Erlebens [The assessment of flow experience]. In J. Stiensmeier-Pelster, \& F. Rheinberg (Ed.), Diagnostik von Motivation und Selbstkonzept (pp. 261-279). Göttingen: Hogref.

Salanova, M., Bakker, A.B., \& Llorens, S. (2006). Flow at work: evidence for an upward spiral of personal and organizational resources. Journal of Happiness Studies, 7, 1-22.

Schaufeli, W.B., \& Bakker, A.B. (2010). Defining and measuring work engagement: Bringing clarity to the concept. In A.B. Bakker, M.P. Leiter (ed.), Work engagement: A handbook of essential theory and research (pp. 10-24). New York: Psychology Press.

Schaufeli, W.B., \& Bakker, A.B. (2003). Work Engagement Utrecht Scale. Preliminary Manual. Utrecht: Occupational Health Psychology Unit.

Schuler, J. (2012). The dark side of the moon. In S. Engeser (ed.) Advances in Flow Research (pp. 123-138). New York: Springer.

Szabowska-Walaszczyk, A. (2010). Zaangażowanie w pracy i organizacji - przegląd problematyki i narzędzi pomiaru [Engagement at work and in organization - review of the issue and tools]. In A.M. Zawadzka (ed.), Psychologia zarzadzania w organizacji [Psychology of management in the organization], (pp. 143-169). Warszawa: Wydawnictwo Naukowe PWN.

\footnotetext{
${ }^{2}$ If you are interested in knowing the current version of the questionnaire please contact the author at the following address: entuzja@entuzja.pl.
} 
Szabowska-Walaszczyk, A., Zawadzka, A.M., Wojtaś, M. (2011). Zaangażowanie w pracę i jego korelaty: adaptacja skali UWES autorstwa Schaufeliego i Bakkera [Work engagement and its correlations: Adaptation of the Schaufeli and Bakker UWES scale]. Psychologia Jakości Życia, t. 10, nr 1, 57-74.

Quinn, R.W. (2004). Flow in knowledge work: High performance experience in the design of national security technology. Working Paper John M. Olin School of Business. Washington University. http:// apps.olin.wustl.edu/workingpapers/pdf/2004-04-001.pdf

Tenenbaum, G., Fogarty, G., \& Jackson, S. (1999). The flow experience: A Rasch Analysis of Jackson's Flow State Scale. Journal of Outcome Measurement, 3(3), 278-294.
Wolfigiel, B. (2003). Jak polubić wysiłek bardziej od lenistwa? Metody osiagania poczucia "przepływu” u osób z różnym zapotrzebowaniem na stymulacje [How to like the effort more than laziness? Methods of achieving flow in people with varying degrees of need for stimulation]. Niepublikowana praca magisterska [Unpublished master thesis]. Katowice: Uniwersytet Śląski.

Zalewska, A. (2002). Skala afektu w pracy - wstępne wyniki prac nad adaptacja techniki [Job Affect Scale - the initial results of the work on adaptation the scale]. Studia Psychologiczne, 40, 4, 172-192. 